\title{
Association study of TAAAA polymorphism in the first intron of $p 53$ gene with risk of colorectal cancer in Iranian population
}

\author{
Zahra Fatehi, Farzane Amirmahani and Manoochehr Tavassoli*
}

\begin{abstract}
Background: Colorectal cancer is the most common gastrointestinal cancer and the third most common cancer over the world. Genetic mutations in the $p 53$ gene are associated with tumorigenesis of most cancers. So far, no study has been conducted on the association between TAAAA repeats in the first intron of the $p 53$ gene and risk of colorectal cancer. In this study, we investigated the association of the TAAAA polymorphism in the first intron of p53 gene with colorectal cancer. We evaluated p53 gene polymorphism in 151 patients with colorectal cancer and a control group of 180 healthy individuals. For TAAAA repeat polymorphism evaluation, we used conventional polymerase chain reaction (PCR) to amplify the desired sequence and the number of TAAAA repeats was specified by polyacrylamide gel electrophoresis and direct sequencing.

Results: In the present study, 5 different alleles of TAAAA repeat with 6-10 repeats and 13 allele genotypes were determined between cases and controls. The most frequent allele in both controls (59.8\%) and cases (57.6\%) was the 8 repeats of TAAAA. Results of homozygous genotypes equal or lower than 8 repeats are higher among the healthy individuals than among the cases. In contrast, the number of genotypes equal or higher than $9(9.10,9.9)$ was higher among the colorectal cancer patients. Because of the small size of the studied population, the statistical analysis did not demonstrate a significant relationship. Also, there is no significant association between genotype, metastasis, and age.
\end{abstract}

Conclusion: Our observations did not show a significant association between the TAAAA repeat polymorphism in the first intron of the $p 53$ gene and the colorectal cancer risk.

Keywords: Colorectal cancer, Association, Polymorphism, P53 gene

\section{Background}

Colorectal cancer $(\mathrm{CRC})$ is the third leading cause of cancer-related deaths over the world [1]. Its development is related to a number of specific genetic changes that promote normal epithelial mucosa into the transformation of carcinomas, such as alternations in APC, $\mathrm{K}-\mathrm{Ras}$, and $p 53$ [2,3]. CRC-related gene identification may help to simplify the early diagnosis, as well as prevention and treatment of the disease. The TP53 tumor suppressor gene, located on chromosome $17 \mathrm{p} 13$, is frequently mutated in most human carcinogenesis [4]. The protein encoded by TP53 is a key regulator in several

\footnotetext{
* Correspondence: manoochehr@biol.ui.ac.ir

Genetic Division, Department of Biology, Faculty of Sciences, University of Isfahan, Isfahan 81746-73441, Iran
}

cellular processes, such as cell cycle arrest, senescence, apoptosis, DNA repair, and alternations in metabolism [5]. Thus, TP53 mutations may cause loss of the protein's tumor suppressor function and therefore result in malignant tumor development [6]. Recently, $p 53$ expression has also been suggested as a prognostic factor in some human cancers in various geographical areas. The existence of significant changes in the mutation patterns between diverse groups of patients with the same cancer proposed that more mutation fingerprints correlated with environmental effects are still to be ascertained [7].

Short tandem DNA repeats are one of the most fluctuating loci in the human genome. They encounter mutations in the copy number of their repeat units at a $10^{-3}$ to $10^{-7}$ rate per cell division [7]. Most of these mutations are due to replication slippage that prevented the 
mismatch repair system proofreading activity [7]. Such instability is also frequently existed in various cancers, such as colorectal, gastric, endometrial, ovarian, and breast cancer [7]. Several researches suggested that gene expression variations are associated with tandem repeat mutations in human carcinomas. For instance, a CAG tri-nucleotide repeat correlated with prostate cancer has been reported in the first exon of the androgen receptor gene. Expansion of this repeat reduces gene expression and improves disease incidence and tumor aggression [7]. High frequency and heterozygosity of the short tandem repeats (STR) in the human genome make them as important tools in genetic studies. In this regard, bioinformatics studies lead to the identification of a region containing a TAAAA STR repeat in the first intron of the $p 53$ gene [8]. Therefore, in this study, we have analyzed TAAAA polymorphism in the first intron of the p53 gene associated with the risk of CRC for the first time.

\section{Methods}

Sample selection

In the present study, blood samples were gathered from 151 CRC cases ( 85 men and 66 women) as well as 180 healthy individuals from Omid Hospital (Isfahan, Iran). They were genetically unrelated and 27-80 years old (mean age 53.5 years) with no cancer history in their families. This study was approved by the ethics committee (acceptance number: 35490/98), and knowledgeable written informed consent for the study was taken from the patients before the blood sample collection. Venous blood samples were gathered in tubes containing ethylene diamine tetra acetic acid (EDTA) and kept at $20^{\circ} \mathrm{C}$.

\section{DNA extraction}

Miller's salting-out method with some modifications [9] was used for DNA extraction from the peripheral blood lymphocytes samples. The quality and quantity of the extracted DNA were respectively evaluated by gel electrophoresis and spectrophotometry.

\section{Separation and amplification of the desired locus}

After DNA extraction, the desired locus was amplified by polymerase chain reaction (PCR) with specific primers designed by OLIGO7 software. The sequences of the primers were presented in Table 1. Ingredients for $25 \mu \mathrm{L}$ reaction volumes are as follows: $2 \mu \mathrm{L}$ of $20 \mathrm{ng} / \mu \mathrm{L}$ genomic DNA, $0.8 \mu \mathrm{L}$ of $10 \mathrm{pmol}$ each inner forward and reverse primers, $0.5 \mu \mathrm{L}$ of $10 \mathrm{pmol}$ each forward and reverse primers, $2.5 \mu \mathrm{L}$ of $10 \times$ PCR buffer, $0.5 \mu \mathrm{L}$ of $10 \mu \mathrm{M}$ dNTPs, $0.25 \mu \mathrm{L}$ of polymerase (CinnaGene, Iran), and $2 \mu \mathrm{L}$ of $\mathrm{MgCl}_{2}(50 \mathrm{Mm})$. PCR was conducted in Eppendorf thermal cycler (Germany) in following conditions: initial denaturation step in $95^{\circ} \mathrm{C}$ for $5 \mathrm{~min}, 33 \mathrm{cy}-$ cles in $95^{\circ} \mathrm{C}$ for $1 \mathrm{~min}$, annealing temperature for $1 \mathrm{~min}$, and $72^{\circ} \mathrm{C}$ for $1 \mathrm{~min}$ followed by a final extension cycle at $72{ }^{\circ} \mathrm{C}$ for $10 \mathrm{~min}$ and then cooled to $4{ }^{\circ} \mathrm{C}$. Finally, the PCR products were separated by electrophoresis on $2 \%$ of agarose gel.

\section{DNA extraction from agarose gel}

In order to extract and purify DNA, DNA purification kit from agarose gel electrophoresis (Fermentase) was utilized according to its manufacturer's protocol.

\section{Determination of the STR copy number}

In order to determine the accurate STR copy number in the first intron of the $p 53$ gene, samples were loaded on a $10 \%$ polyacrylamide gel. After determining the appropriate alleles as markers for identification of the other ones, they were sequenced by CinnaGene Company (Tehran, Iran) following PCR amplification.

\section{Statistical analysis}

After determining the copy number of TAAAA repeats, the allelic and genotype frequencies were analyzed by SISA online database. Genotype and allele frequencies between cases and controls were compared using $X^{2}$ test. The odds ratio (OR) with $95 \%$ confidence intervals (CIs) was applied to determine the association between the polymorphism and risk of CRC. Also, $P<0.05$ was considered as a statistically significant level.

\section{Results}

Determination of the allele frequencies in the $p 53$ gene

After the amplification of the extracted DNA samples by $\mathrm{PCR}$, in order to determine the TAAAA repeats of the p53 gene, the samples were loaded on a $10 \%$ polyacrylamide gel (Fig. 1).

In this study, five different alleles, between six and ten repeats, were determined for cases and controls. Among these alleles, allele 8 was the most prevalent allele in cases (57.6\%) and controls (58.9\%). The least allele frequency belongs to the six repeat alleles (1.6\%) in cases and six and ten repeat alleles (1.1\%) in controls. The

Table 1 Primer sequences for TAAA repeated sequence in the $p 53$ gene

\begin{tabular}{lllll}
\hline Gene name & Amplified sequence name & Amplified region & Primer & Sequence $\left(5^{\prime}-3^{\prime}\right)$ \\
\hline p53 & (TAAAA)n & Intron & $\mathrm{F}$ & AATCCGGGAGGAGGTTGCAG TAAG \\
& & $\mathrm{R}$ & ACAGCTCCTTTAATGGCAGG CTCTIT \\
\hline
\end{tabular}




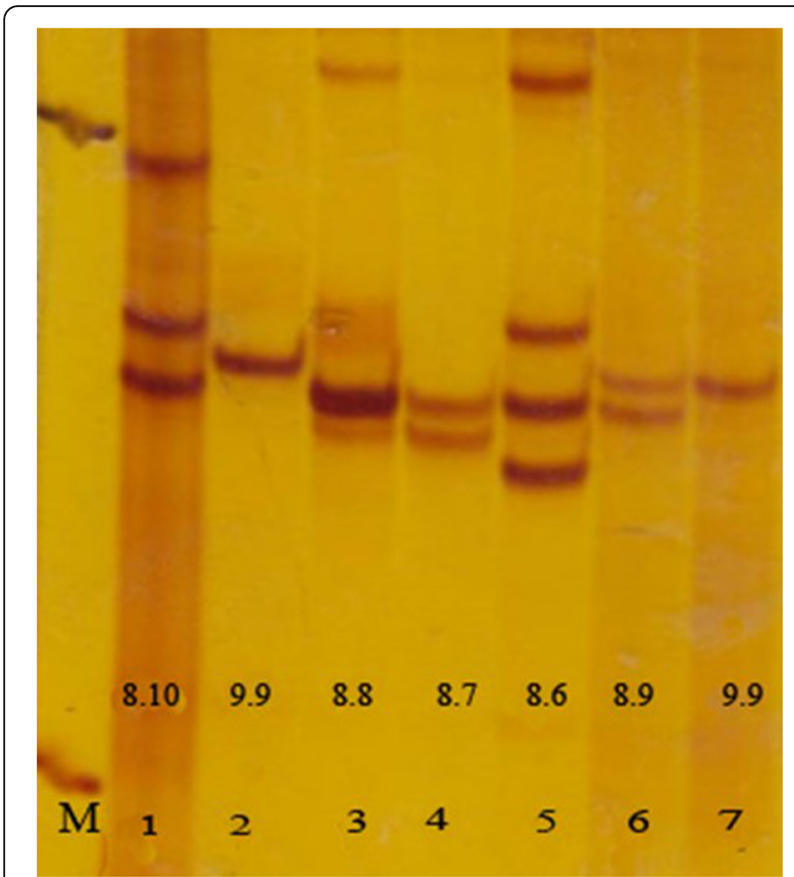

Fig. 1 Ten percent polyacrylamide gel for TAAAA polymorphism association study. The results are shown with a 100-bp DNA marker. Rows (1-7) show the allelic variations of the TAAAA repeats in the studied population

allele frequencies and their association with CRC were presented in Table 2.

\section{Determination of the genotype frequencies in the $p 53$ gene}

In the studied population, 13 different genotypes were observed for the $p 53$ gene. The obtained results showed that the most frequent genotype in both cases (33.3\%) and controls (35.5\%) was 8/8 genotype. Furthermore, 6/ 7 allele was only observed in cases and 6/6 and 7/10 alleles were in controls. The genotype frequencies in cases and controls were shown in Table 3. A difference in distribution was observed in homozygous genotypes with equal to or lower than eight repeats. The number of these genotypes was higher in controls than in cases. The number of genotypes equal to or larger than nine repeats (9/9 and 9/10) was higher in cases than in

Table 2 The different allele frequencies of the p53 gene between cases and controls

\begin{tabular}{lllll}
\hline Allele & Case (151) & Control (178) & OR (95\%Cl) & $P$ \\
\hline 6 & $5(1.6)$ & $4(1.1)$ & $1.481(0.394-5.567)$ & 0.399 \\
7 & $52(17.2)$ & $73(20.5)$ & $0.806(0.544-1.196)$ & 0.609 \\
8 & $173(57 / 3)$ & $213(59.8)$ & $0.9(0.66-1.229)$ & 0.841 \\
9 & $66(21.8)$ & $62(17.4)$ & $1.135(0.771-1.671)$ & 0.811 \\
10 & $6(2.0)$ & $4(1.1)$ & $1.784(0.499-6.381)$ & 0.504 \\
Total & 302 & 356 & & \\
\hline
\end{tabular}

Table 3 The frequencies of different genotypes of TAAAA repeats in the $p 53$ gene between cases and controls and their association with the risk of CRC

\begin{tabular}{lllll}
\hline Genotype & Case & Control & OR $(95 \% \mathrm{Cl})$ & $P$ \\
\hline 6.6 & $0(0.0)$ & $1(0.5)$ & & \\
6.7 & $1(0.7)$ & $0(0.0)$ & & \\
6.8 & $3(2)$ & $1(0.5)$ & $3.628(0.373-35.248)$ & 0.376 \\
6.9 & $1(0.7)$ & $1(0.5)$ & $1.193(0 / 074-19 / 241)$ & 0.075 \\
7.7 & $3(2)$ & $8(4.4)$ & $0.436(0.114-1.673)$ & 0.121 \\
7.8 & $34(22.5)$ & $41(22.7)$ & $0.985(0.588-1.652)$ & 0.663 \\
7.9 & $11(7.3)$ & $15(8.3)$ & $0.864(0.384-1.943)$ & 0.414 \\
7.10 & $0(0.0)$ & $1(0.5)$ & & \\
8.8 & $47(31.1)$ & $64(35.5)$ & $0.819(0.517-1.298)$ & 0.643 \\
8.9 & $40(26.5)$ & $41(22.7)$ & $1.222(0.74-2.018)$ & 0.797 \\
8.10 & $2(1.3)$ & $2(1.1)$ & $1.195(0.166-8.584)$ & 0.17 \\
9.9 & $5(3.3)$ & $4(2.2)$ & $1.507(0.397-5.714)$ & 0.407 \\
9.10 & $4(2.6)$ & $1(0.5)$ & $4.871(0.539-44.053)$ & 0.539 \\
Total & 151 & 180 & & \\
\hline
\end{tabular}

controls (Table 4). According to these observations, no significant association was observed between these genotypes and risk of CRC. Also, there was no significant association between these genotypes, metastasis, and age.

\section{Discussion}

Nowadays, in cancer therapy, researchers consider procedures and molecular mechanisms related to carcinogenesis [10]. p53, as a tumor suppressor gene, have significant roles in many cellular processes including apoptosis, necrosis, autophagy, and senescence [11]. In response to the DNA damage, $p 53$ controls key processes, such as DNA repair, cell cycle arrest, senescence, and apoptosis, to suppress tumors [12]. Also, in response to stress, $p 53$ plays an important role in preventing cancer progression [13]. p53 affects the efficacy of chemotherapy and radiotherapy, and researches showed that an active pathway of $p 53$ is necessary for chemotherapy and radiotherapy [14]. Loss-of-function mutations in the $p 53$ gene were detected in $54 \%$ of human cancers, including CRC [15]. These mutations are presented in five main codons, such as $155,245,248,253$, and 282 [16]. Mutation in one copy of the $p 53$ gene and loss of the other copy are observed in many cancer types including CRC [17]. This phenomenon suggests that loss of both copies of the p53 gene is necessary for tumorigenesis. There has been no study on the presence of TAAAA repeat polymorphism in the first intron of the $p 53$ gene and its association with the risk of CRC. In the present study, we have performed this subject through a case-control study in Isfahan population (Iran). In this prospective study, we determined the number of TAAAA repeats in 
Table 4 Association between homozygous genotypes and risk of CRC

\begin{tabular}{lllll}
\hline Genotypes & Case & Control & OR (95\%Cl) & $P$ \\
\hline $6.6+7.7$ & $3(1.9)$ & $9(5.0)$ & $0.38(0.10-1.45)$ & 0.13 \\
$6.6+7.7+8.8$ & $50(33.1)$ & $73(40.5)$ & $0.72(0.46-1.14)$ & 0.16 \\
Both alleles equal or larger than 9 & $9(5.9)$ & $5(2.8)$ & $2.2(0.72-6.77)$ \\
\hline
\end{tabular}

a sample of 151 subjects with CRC and 180 healthy individuals. To do this, we first amplified the repeated region by PCR, and then, we accurately determined the number of TAAAA repeats in all subjects by polyacrylamide gel electrophoresis. Finally, a statistical analysis was performed to determine the number of TAAAA repeats and its association with CRC.

Based on the obtained results, 5 different alleles for TAAAA repeat polymorphism between 6 and 10 repeats were detected in cases and controls. Among these alleles, the allele with 8 repeats was the most frequent allele in both cases and controls. Among all studied population, 13 genotypes were observed for the $p 53$ gene. The results of the genotype analysis showed that the most frequent genotype in cases and controls belonged to 8.8 genotype. The polymorphism of TAAAA repeat was also evaluated in the promoter region of the lipoprotein A gene. This polymorphism was associated with enhanced transcription activation and increased plasma levels of the lipoprotein A [18]. There was an inverse relationship between the 5 repeats of the TAAAA and lipoprotein level [19]. In the present study, the number of the TAAAA alleles and their frequencies are similar to the previous ones for lipoprotein A gene with the difference that we have not observed the 5 repeat alleles. In addition, there was no significant association between the homozygote genotypes and the risk of CRC. The reason for this observation is probably the low number of the desired genotypes, and with increasing the number of samples, the probability of association also increases.

STRs or microsatellite DNAs may be presented in enhancer sequences and affect the gene expression that can be used as prognostic factors for cancer therapy [20, 21]. Also, these repeated sequences can be existed in the introns and affect the gene expression through intron dissipation rate alternation [22-24]. STRs presented in the introns can also affect different products of intron splicing and create different isoforms [24]. Some isoforms of the $p 53$ gene lack the $\mathrm{N}$-terminal region of transcription activation; therefore, it is possible that the small homozygotes of the $p 53$ gene with six and five repeats would lead to a decrease in the $p 53$ gene expression or to contribute to produce inhibitor isoforms without the $\mathrm{N}$-terminal region. A similar study performed by Njafi et al. on the TAAAA repeats in breast cancer showed that the number of 7.7 genotype was more in controls than in cases and this association was significant $(P=0.01, \mathrm{OR}=4.5[25])$. It is possible that intermediate proteins will differ in the production of isoforms or expression in breast and colon cells.

\section{Conclusion}

In the present study, the association between TAAAA repeats in the $p 53$ gene and risk of CRC were evaluated in Isfahan population (Iran). However, despite the difference in the distribution of some genotypes in cases and controls, no significant association was found between the number of repeats and CRC.

\section{Abbreviations}

APC: Adenomatous polyposis coli; CRC: Colorectal cancer; OR: Odds ratio; PCR: Polymerase chain reaction; STR: Short tandem repeats

\section{Acknowledgements}

This study has been conducted in the genetics lab at the University of Isfahan (Iran). We would like to acknowledge all the physicians and nurses of Omid Hospital especially Dr. Simin Hemmati for the clinical data.

\section{Authors' contributions}

MT designed and supervised the experimental work. ZF did the experimental procedures. FA and ZF analyzed the data and wrote the manuscript. All authors have read and approved the manuscript.

\section{Funding}

The design of the study and the collection, analysis and interpretation of the data supported financially by the Departments of Research/Technology and Graduate Offices at the University of Isfahan (Iran).

\section{Availability of data and materials}

The datasets used and/or analyzed during the current study are available from the corresponding author on reasonable request.

\section{Ethics approval and consent to participate}

This study is approved by Omid Hospital (Isfahan, Iran) review board and also the ethics committee of Isfahan University (Iran) (acceptance number: 35490/98). A written informed consent form was obtained from each patient according to the Declaration of Helsinki.

\section{Consent for publication}

Not applicable.

\section{Competing interests}

The authors declare that they have no competing interests.

Received: 29 June 2019 Accepted: 13 September 2019

Published online: 23 October 2019

\section{References}

1. Zeuner A, Todaro M, Stassi G, De Maria R (2014) Colorectal cancer stem cells: from the crypt to the clinic. Cell Stem Cell 15(6):692-705

2. Fearon ER, Vogelstein B (1990) A genetic model for colorectal tumorigenesis. cell 61(5):759-767

3. Ullman TA, Itzkowitz SH (2011) Intestinal inflammation and cancer. Gastroenterology 140(6):1807-1816 e1 
4. Tsui IF, Poh CF, Garnis C, Rosin MP, Zhang L, Lam WL (2009) Multiple pathways in the FGF signaling network are frequently deregulated by gene amplification in oral dysplasias. Int J Cancer 125(9):2219-2228

5. Berchuck A, Kohler MF, Marks JR, Wiseman R, Boyd J, Bast RC Jr (1994) The p53 tumor suppressor gene frequently is altered in gynecologic cancers. Am J Obstet Gynecol MFM 170(1):246-252

6. Francisco G, Menezes PR, Eluf-Neto J, Chammas R (2011) Arg72Pro TP53 polymorphism and cancer susceptibility: a comprehensive meta-analysis of 302 case-control studies. Int J Cancer 129(4):920-930

7. Pages F, Galon J, Dieu-Nosjean M, Tartour E, Sautes-Fridman C, Fridman W (2010) Immune infiltration in human tumors: a prognostic factor that should not be ignored. Oncogene. 29(8):1093

8. Calafell F, Shuster A, Speed W, Kidd J, Kidd K (1998) Short tandem repeat polymorphism evolution in humans. Eur J Hum Genet 6(1):38

9. Jamalvandi M, Motovali-bashi M, Amirmahani F, Darvishi P, Goharrizi KJ (2018) Association of T/A polymorphism in miR-1302 binding site in CGA gene with male infertility in Isfahan population. Mol Biol Rep 45(4):413-417

10. Amirmahani F, Motovali-Bashi M, Samani ZG (2017) Association scrutiny between the miRNA 148a/152 polymorphisms and risk of breast cancer in Isfahan population

11. Chen J (2016) The cell-cycle arrest and apoptotic functions of $p 53$ in tumor initiation and progression. Cold Spring Harb Perspect Med 6(3):a026104

12. Meek DW (2009) Tumour suppression by p53: a role for the DNA damage response? Nat Rev Cancer 9(10):714

13. Evan Gl, Vousden KH (2001) Proliferation, cell cycle and apoptosis in cancer. Nature 411(6835):342

14. Brognard J, Clark AS, Ni Y, Dennis PA (2001) Akt/protein kinase B is constitutively active in non-small cell lung cancer cells and promotes cellular sunvival and resistance to chemotherapy and radiation. Cancer Res 61(10):3986-3997

15. Goh H-S, Yao J, Smith DR (1995) p53 point mutation and survival in colorectal cancer patients. Cancer Res 55(22):5217-5221

16. Tominaga T, Iwahashi M, Takifuji K, Hotta T, Yokoyama S, Matsuda K et al (2010) Combination of $p 53$ codon 72 polymorphism and inactive $p 53$ mutation predicts chemosensitivity to 5 -fluorouracil in colorectal cancer. Int J Cancer 126(7):1691-1701

17. Lenz $\mathrm{H}-\mathrm{J}$, Hayashi K, Salonga D, Danenberg KD, Danenberg PV, Metzger R et al (1998) p53 point mutations and thymidylate synthase messenger RNA levels in disseminated colorectal cancer: an analysis of response and survival. Clin Cancer Res 4(5):1243-1250

18. Nascimento H, Silva L, Lourenço P, Vieira E, dos Santos R, Rego C et al (2009) Lipoprotein (a) levels in obese Portuguese children and adolescents: contribution of the pentanucleotide repeat (TTTA) $n$ polymorphism in the apolipoprotein (a) gene. Arch Pediatr Adolesc Med 163(4):393-394

19. Berglund L, Ramakrishnan R (2004) Lipoprotein (a) an elusive cardiovascular risk factor. Arterioscler Thromb Vasc Biol 24(12):2219-2226

20. Agarwal AK, Giacchetti G, Lavery G, Nikkila H, Palermo M, Ricketts M et a (2000) CA-repeat polymorphism in intron 1 of HSD11B2: effects on gene expression and salt sensitivity. Hypertension. 36(2):187-194

21. Mohammadi M, Amirmahani F, Goharrizi K, Pakzad R, Dolat H (2019) Evaluating the expression level of Survivin gene in different groups of B-cell acute lymphoblastic leukemia patients of Iran. Mol Biol Rep 46(3):2679-2684

22. Suzuki M, Kageyama S, Shinmura K, Okudela K, Bunai T, Nagura K et al (2008) Inverse relationship between the length of the EGFR CA repeat polymorphism in lung carcinoma and protein expression of EGFR in the carcinoma. J Surg Oncol 98(6):457-461

23. Sharma VK, Kumar N, Brahmachari SK, Ramachandran S (2007) Abundance of dinucleotide repeats and gene expression are inversely correlated: a role for gene function in addition to intron length. Physiol Genomics 31 (1):96-103

24. Gemayel R, Cho J, Boeynaems S, Verstrepen KJ (2012) Beyond junk-variable tandem repeats as facilitators of rapid evolution of regulatory and coding sequences. Genes. 3(3):461-480

25. Najafi-Dorche S, Tavassoli M, Hemati S, Safari F (2015) The study of TAAAA polymorphism in $p 53$ gene and its association with breast cancer, pp 134-143

\section{Publisher's Note}

Springer Nature remains neutral with regard to jurisdictional claims in published maps and institutional affiliations.

\section{Submit your manuscript to a SpringerOpen ${ }^{\circ}$ journal and benefit from:}

- Convenient online submission

- Rigorous peer review

- Open access: articles freely available online

- High visibility within the field

- Retaining the copyright to your article

Submit your next manuscript at $\boldsymbol{\nabla}$ springeropen.com 